\title{
Mt Apo and other national parks in the Philippines
}

\author{
Richard E. Lewis
}

In 1984 international attention was focused on Mt Apo National Park in the Philippines when the IUCN declared it one of the world's most threatened protected natural areas. Human settlements had destroyed large areas of the park and in 1983 the Philippine Government reclassified over half of the park for agricultural development, although this was revoked in 1986. The author lived in the park while working on the Philippine Eagle Conservation Programme, witnessing the problems first-hand. He describes the park and the problems it faces, which he believes could be overcome.

\section{Mt Apo National Park}

Mt Apo National Park (72,814 ha) is located on the southern island of Mindanao in the Philippines. It covers the volcanic massif formed by Mt Apo, at $2954 \mathrm{~m}$ the highest peak in the Philippines, and Mt Talomo $(2674 \mathrm{~m})$. Mt Talomo is extinct, and its many peaks are the eroded remnants of an old crater rim. Mt Apo's last recorded eruption was in 1640, with most of the lava being deposited on the western slopes (Kellman, 1970). Although it now appears dormant, there are still numerous vents below the peak, from which issue steam and sulphurous gases.

There is little seasonal variation in the climate around Mt Apo, which lies just outside the cyclonic belt that affects the central and northern Philippines. Rain falls in every month of the year, although it tends to be greatest between June and December.

\section{Vegetation}

No comprehensive floral survey has been undertaken, and some parts of the park remain unexplored. The vegetation types described are based upon surveys of the eastern slopes conducted by the Bureau of Forest Development (ASEAN Experts Group on the Environment, 1983) and by Kellman (1970).

100
In the peak area, massive boulders are interspersed with small bushes, and short grasses grow on the flat areas. Below about $2700 \mathrm{~m}$ extensive mossy forest begins and extends over Mt Talomo. This forest is one of the most spectacular sights in the park. The gnarled and twisted oak trees (Lithocarpus spp. and Podocarpus spp.), Syzygium malagsam and Dacrycarpus cumingii are covered in moss and epiphytes and form a canopy 5-10 m high. Most of the year it is dark and damp, and in many places one can walk over a network of mosscovered roots with the forest floor a metre or so below.

Below about $1500 \mathrm{~m}$ the mossy forest gives way to drier forest whose canopy is $20 \mathrm{~m}$ high, with occasional emergent trees up to $40 \mathrm{~m}$ tall. The most common emergents are Shorea spp. (especially S. almon) and Lithocarpus spp. Canopy trees also include these species, as well as Astrocalyx calycina, Syzygium spp. and Cinnamomum spp. Less important trees include Arthocarpus spp., Canarium spp., Ficus spp., Lasianthus spp., Clethra canescens and various species of the Longaniaceae. The Almacega tree Agathis dammara is found here, but unfortunately many have been killed or removed. It is a source of resin and also a much prized wood in the furniture industry. Some of the older strangling figs Ficus spp. are hollow, Oryx Vol 22 No 2, April 1988 
having killed the host tree. These are normally left alone by local people who believe they are inhabited by spirits. Most of this forest (especially at the lower altitudes) is secondary growth due to landslips, logging and cultivation. Tree ferns (Cyathea contaminans and C. elmeri) are common in clearings and on forest edges, as are Saurauia spp. and screw-pines (Pandanus spp.).

At about $1000 \mathrm{~m}$ the forest develops into a true dipterocarp forest (Shorea spp., Parashorea spp. and Dipterocarpus spp.) (FAO, 1981), with a higher canopy and trees $50 \mathrm{~m}$ tall, or more. Most of this forest has already been cleared, but remnants can still be found on the sides of gorges, for example, along the Sibulan river. Figure 1 shows the areas occupied by forest in the park during the 1970s and the main settlements in the area.

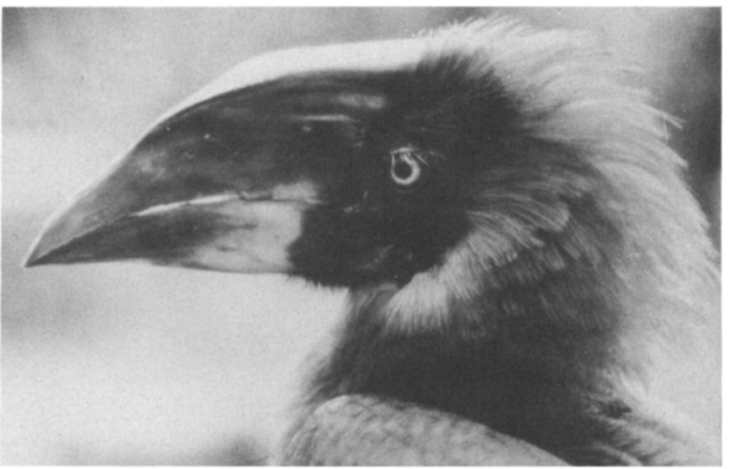

Rufous hormbill Buceros hydrocorax, endemic to the Philippines and found throughout the park (R. E. Lewis)

Below: Figure 1. Map of Mt Apo National Park (adapted from Sorongon, 1982).

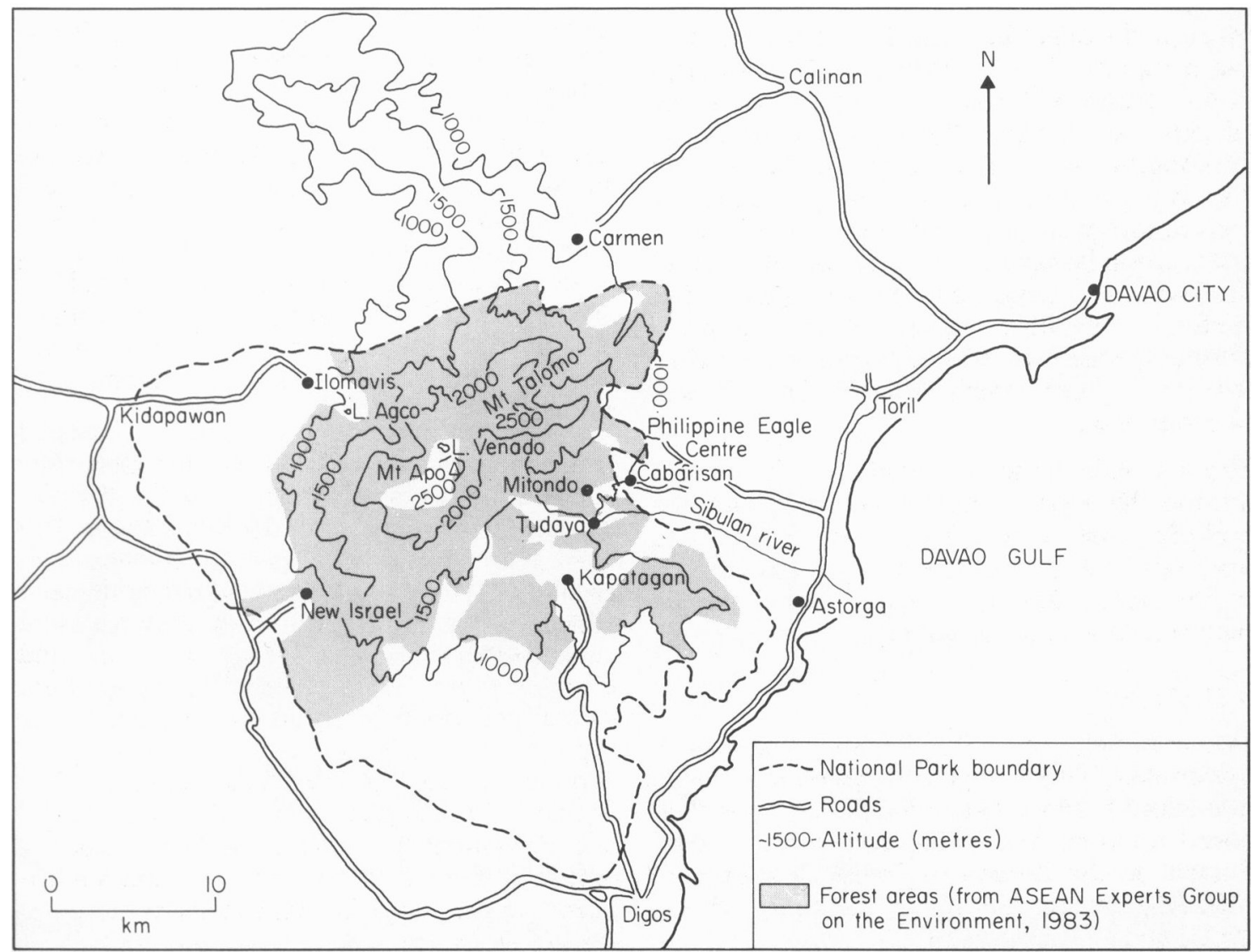




\section{Fauna}

The most famous inhabitant of the park is the Philippine eagle Pithecophaga jefferyi, and the Philippine Eagle Conservation Programme (PECP) is based there. The birds of the park have been recorded, but little is known of their biology. Of the total number of bird species recorded there, 61 species are endemic to the Philippines and 14 of these are endemic to Mindanao (Table 1).

The larger mammals in the park are deer Cervus mariannus, the Philippine warty pig Sus barbatus philippensis and the crab-eating macaque Macaca fascicularis. Other mammals include the Philippine flying lemur Cynocephalus volans, civet cats Paradoxurus hermaphroditis and Viverra tangalunga, fruit bats Pteropus vampyrus and Acerodon jubalatus, the Mindanao flying squirrel Hylopetes mindanensis, and the Mindanao tree shrew Urogale everetti. The endangered Philippine tarsier Tarsius syrichta may possibly still be found in the park, but it is primarily a species of lowland forest, most of which has already been destroyed. In the mossy forest lives the insectivore Podogymnura truei, a relict species restricted to the highlands of Mindanao. Its only congener $P$. aureospinula is found on the island of Dinagat (Figure 2) (W. Poduschka, pers. comm.).

Little is known of the reptiles in the park. A recent survey of these by the $\mathrm{PECP}$ is soon to be published (Kennedy and Catibog-Sinha, in prep.).

\section{The importance of Mt Apo National Park}

Hauge et al. (1986) have estimated the relative importance of the various islands within the Philippine archipelago, with regards to their vertebrate wildlife. The three most important (in terms of number of species and degree of endemicity) are Mindanao, Luzon and Palawan, in that order. Protecting the natural biotas of these three islands would preserve 86 per cent of all the Philippine vertebrates and 70 per cent of the 'single-island endemics'.

Mt Apo National Park contains forest habitat typical of central Mindanao, supporting both 102
Table 1. Birds of Mt Apo, endemic to Mindanao (classification based on Bruce, 1980; Kennedy, an unpublished checklist)

Trichoglossus johnstoniae Mindanao lorikeet

Prioniturus waterstradti Mindanao racket-tailed parakeet

Halcyon hombroni Blue-capped wood kingfisher

Leonardina woodi Bagobo babbler

Rhinomyias goodfellowi Goodfellow's jungle flycatcher

Rhipidura

nigrocinnamomea

Basilornis miranda

Aethopyga primigenius

A. boltoni

Dicaeum proprium

D. nigrilore

Lophozosterops goodfellowi

Hypocryptadius cinnamomeus

Erythrura coloria Black and cinnamon fantail

Apo myna

Hachisaka's sunbird

Apo sunbird

Slaty-breasted flowerpecker

Olive-capped flowerpecker

Apo white-eye

Cinnamon white-eye

Red-eared parrotfinch

The only other species endemic to Mindanao, the sharp-tailed cuckoo-shrike Coracina mcgregori can be found on $\mathrm{Mt}$ Katanglad and Mt Malindang. It may possibly also exist on the northern side of Mt Apo.

Philippine endemic plants and animals and Mindanao highland endemics. It is one of the only two ASEAN* Natural Heritage Parks in the country (the other is Mt Iglit on Mindoro) (Figure 2), and one of only two large forested parks on Mindanao.

The forests in the park are also an invaluable watershed for Davao City, the second largest city in the country, whose water supply is piped from the foothills of Mt Apo. The main agricultural crops of the lands surrounding the park are coconut and paddy rice, the latter needing an abundant and constant water supply. Most days the peak is hidden by clouds in the afternoon, often with the cloud level as low as 1000 $\mathrm{m}$. The Philippine Eagle Centre staff and Kellman (1970) have recorded yearly rainfall at this height as being almost twice as much as that received by Davao City.

\section{The history of the park}

Mt Apo National Park was created in 1936 to protect the unique scenery of the volcano and the surrounding rain forest. Although originally 76,900 ha, small areas were lost from the park in

*Association of South-East Asian Nations (Philippines, Thailand, Singapore, Malaysia, Brunei and Indonesia).

Oryx Vol 22 No 2, April 1988 


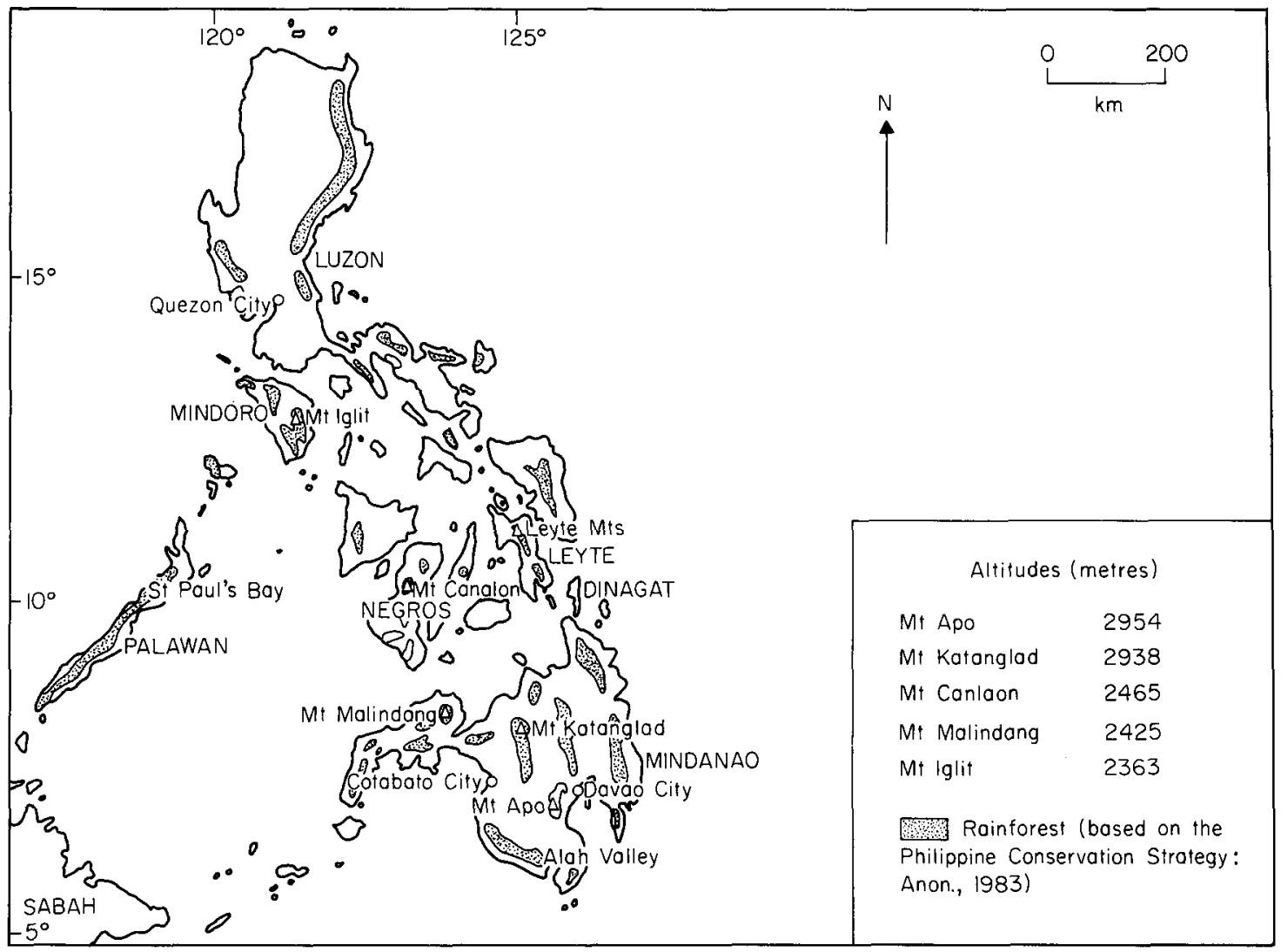

Figure 2. Map of the Philippines illustrating the rain forest and protected forest areas mentioned in the text.

1957 and 1965, and then again in 1965 the park was reduced to 33,764 ha. The park was restored to 72,814 ha the following year (Anderson et al., 1983).

Various tribal peoples live in the park: the Manobos live in the west, around llomavis, and various tribes of Bagobos live in the south and east. Both groups are shifting cultivators and still hunt in the forest. The Bagobo village of Tudaya (Figure 1) has been in existence at least all this century and was, until recently, the highest settlement $(1000 \mathrm{~m})$ in the park. In previous times the Bagobos worshipped the spirit of the volcano, 'Sandawa'. This religion still exists in parts of the mountain, although virtually all Bagobos are now Christian and little is practised of their native culture. In the very north of the park live the Aetas (also known as Negritos). These people are the earliest colonizers of the country and are very National parks in the Philippines different from the Malay-types like Bagobos and Manobos. The Aetas are not permanent settlers but nomadic hunters within the forest, dependent on the forest for their livelihoods. These native groups retain important knowledge about the plants of the forest and the use of the forest as a sustainable resource. Any longterm plan for the park has to include a realistic future for these people.

Currently the predominant crop in the mountains is coffee, which is grown as a cash crop and carried by pony to the road terminals. These plantations are maintained over many years; each year they are underbrushed and the coffee bushes mulched with the cut vegetation. Most is grown below productive capacity as the bushes are not pruned properly and many are too old. Maize and Manila hemp Musa textilis are also grown as cash crops and cassava, taro and sweet potato for domestic consumption. 
Many parts of the park are now non-viable as forest reserves. In the mid-1970s it was estimated that 20 per cent of the park had already been converted to open lands (Anderson et al., 1983). Probably over 50 per cent of the park is now deforested, and the resultant fragmentation of the forest increases the threat to wildlife. Philippine eagles, for example, require large areas of forest (Lewis, 1986) and the remaining areas around Mt Apo probably do not support more than 15 pairs (Kennedy and CatibogSinha, in prep.), an already dangerously low number. The nearest forests to Mt Apo are at least $20 \mathrm{~km}$ away, which must limit immigration and emigration and increase the likelihood of localised extinction from genetic deterioration or environmental catastrophe.

\section{Administration}

National parks are administered by at least ten different bodies, including three Ministries and two universities. The majority, including Mt Apo National Park, come under the jurisdiction of the Parks and Wildlife Division, a department of the Bureau of Forest Development (BFD), which is part of the Ministry of Natural Resources (MNR). However, as a non-revenue earner for the BFD (most of which is concerned with the monitoring of logging), the Parks and Wildlife Division has been under-budgeted and under-staffed.

Mt Apo National Park is administered by two separate regional BFD offices, Region XI based at Davao City and Region XII at Cotabato City (Figure 2). This has led to problems with each region working independently of the other over park issues.

In the past, administration of the park has been hampered by the presence of rebels. Conditions are still unsettled in the northern areas of the park, but I found that a great deal of work could still be accomplished. There is a lot of public sympathy towards conservation and this was reflected in the attitude of both the military and the rebels who tended to leave us alone. The southern area of the park has always been safe and visitors trek to the peak unharassed. Working in the park demands patience, but progress can be achieved. It is to be hoped that conditions may improve in the highlands.

\section{Threats}

In March 1983, under new legislation governing land classification, 44,772 ha of the park were declared 'alien and disposable', transferring them from the Ministry of Natural Resources to the Ministry of Human Settlements. The justification for this was that the lands in question were already under cultivation, but a BFD survey estimated that only about 35 per cent of these lands were under crops. The Philippine Eagle Centre and surrounding forest were in one of the 'alien and disposable' areas and were scheduled to be developed for plantations. This action brought strong protest from the international community, which halted the implementation of the new law. As a result the park was placed 'in limbo' with neither ministry acting. Legally the park was reduced to a mere 28,032 ha. At this size, it was questioned whether the park was a viable biological entity. Other parks were affected by the same law. The situation changed in June 1986 when the Aquino government revoked the March 1983 law and the disputed areas returned to the Ministry of Natural Resources, Mt Apc National Park reverting to 72,814 ha.

The biggest threat to the park is the massive inflow of lowlanders, who have no knowledge 0 : living in the mountains. They enter the fores along the logging roads, clearing and settlins the already 'thinned forest' (Lewis, 1986). The slash-and-burn clearings are known as kaingins and the clearers kaingineros. The kainginero is one of the largest social problems in the country. Efforts are under way to resolve this notably on the island of Palawan (Gaon, 1984) When they have no chain-saws, the kainginero: cut down the trees by axe 3-5 $\mathrm{m}$ from the ground to avoid the labour of cutting through the wide buttresses at the base of the tree. Al the undergrowth is burnt back during the $\mathrm{dr}$ season (January-May around Apo). The crop: are grown between the fallen tree trunks, as ir the mountains it is impractical to saw the tree: for lumber, unless needed for local housi building. During the drought of 1982/83, condi tions were so dry that kaingineros were able tc fire the intact forest and uncontrolled fires ragec over Mindanao. Mt Apo suffered less thar many parts of the island.

Oryx Vol 22 No 2, April 198 
In the early to mid-1970s, 2000 ha of forest were logged on the high plateau of Kapatagan (Figure 1) (Pollisco, 1982) and now a township exists there with a satellite village Pog-Pog, established at $1200 \mathrm{~m}$. The new generations of Bagobos, in places like Tudaya and Mitondo, have no alternative but to go higher in the mountains as the lower areas are populated. A 1975 survey (Anderson et al., 1983) put the total number of inhabitants in the park at 15,000. Probably a realistic figure now would be over 20,000.

A new road is under construction (completion expected in 1995) to link Tudaya with the main highway at Astorga. Although this will be a boon for the villagers exporting their produce, it will probably mean another inflow of people into the park, and create good conditions for illegal logging.

Uncontrolled hunting and collecting still continue in the park. Hunting and trapping are primarily for pigs and deer; monkeys are also shot when they raid kaingins. Epiphytes, bamboos and rattans are commonly collected for household use. It is not known what impact this exploitation is having inside the forest, but rattans have certainly been depleted in many areas. Parrots are still collected illegally in the park, primarily for the domestic market. Many colourful butterflies and orchids are also under pressure from uncontrolled collection. The orchid 'Waling-Waling' Vanda sanderiana fetches very high prices even on the domestic market. Butterfly collection is presently a more specialized pursuit, but may be having an equally strong effect on some species. The swallowtail Graphium sandawanum, which is confined to $\mathrm{Mt} \mathrm{Apo,} \mathrm{is} \mathrm{threatened} \mathrm{as} \mathrm{the} \mathrm{forest}$ is destroyed (Collins and Morris, 1985).

\section{Recommendations}

Reorganization and committed finance are needed for the Parks and Wildlife Division. Ideally, Mt Apo National Park should be wholly controlled from one region by a full-time park warden. Otherwise control should be returned to the central office of the BFD at Quezon City. More forest guards need to be assigned to protecting the park; presently they are too few, and trained in forestry and logging rather than in wildlife and park management. The Australian Government together with AREA (Association for Research Exploitation and Aid) has offered to train park rangers and help create a Philippine ranger service (Warren, 1982).

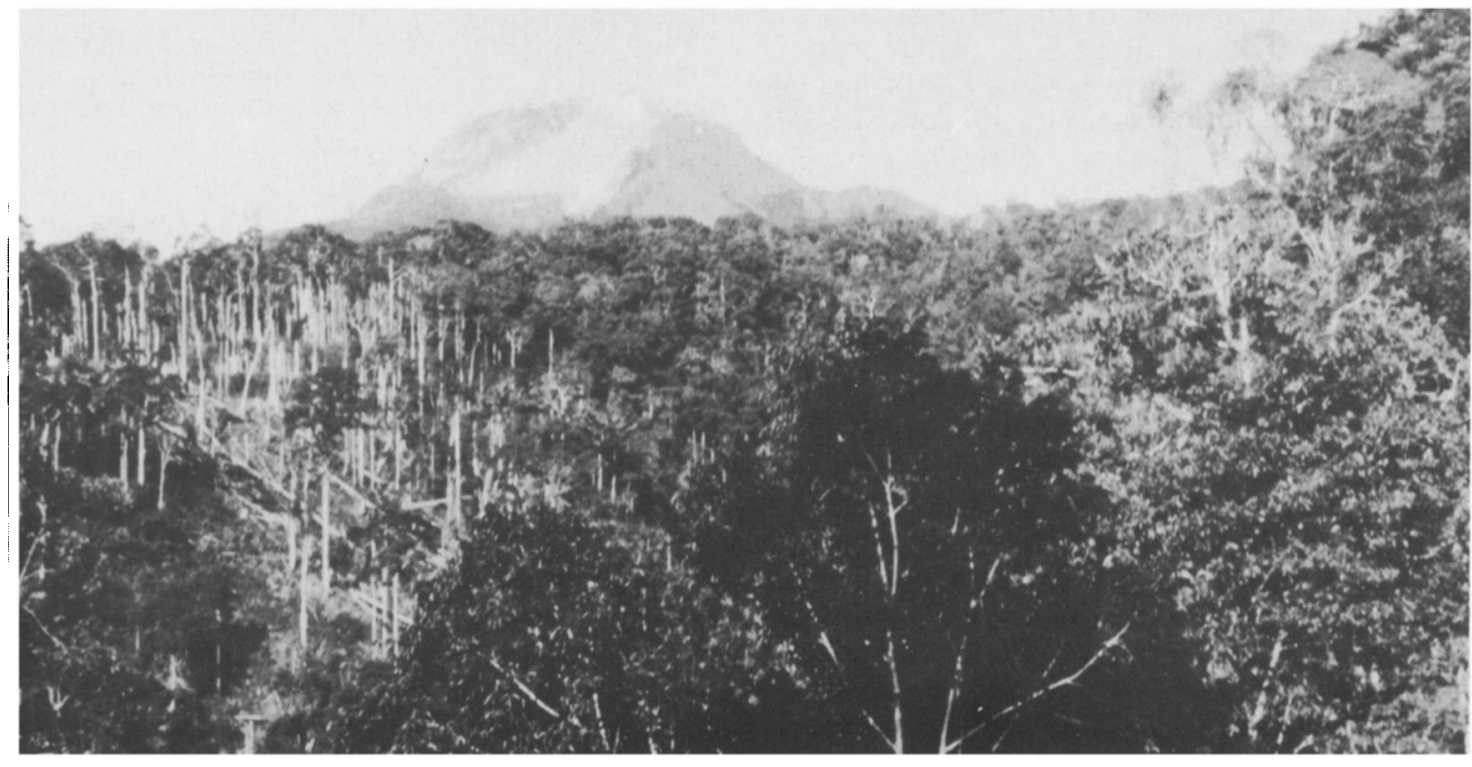

Mt Apo as seen from Mitondo (R. E. Lewis). 
A ground survey is needed to assess the number, and nature, of settlements and the areas of remaining forest. Landsat and aerial photographs are already available. Forest areas still exist outside the park, on its northern boundary, and even if already logged they may still have good potential for park inclusion. It is important that the forest area of the park is increased to counteract the clearances, otherwise the park's viability as a representative biotope will be lost. Although new areas of forest need to be included, the denuded areas, such as at Kapatagan, should not be fully excluded from the park lest this encourage further settlements. A zonation policy is needed with a core zone fully protected and subject to strict control over usage. Settled areas of the park would be a secondary zone, still under park guidance, and with any developments aimed at creating a buffer to, and alleviating demands on, the forest. Agro-forestry techniques would produce income for the settlers as well as maintain stable soil conditions. Large areas of the park that have been degraded to cogon grass Imperata cylindrica should be reclaimed. Cogon areas, which are created by repeated burning, are extremely unproductive and can only provide grazing when new shoots are growing. Presently 15-20 per cent of the whole country is estimated to be covered in cogon grass, and a further 20 per cent is considered to be marginal land unsuitable for lowland agriculture (Anon., 1983). If these lands are put to a more productive use then pressure on the forest would be alleviated. Few lowlanders want to live in the harsh conditions high in the mountains.

\section{Public participation in education}

During the drought of $1982 / 83$, part of the mossy forest on Mt Apo was burnt in a fire that was probably started accidentally by campers. In late 1983 a reafforestation programme was carried out. Many of the seedlings planted were exotics, but it was felt that these would still be useful in maintaining the soil and providing suitable conditions for the indigenous forest to regrow. The seedlings were provided by the BFD and two climbing groups, MACADAC (Mt Apo Climbers' Association of Davao City) and the parent group, the National Mountain106 eering Federation, provided the labour. The Federation mobilized all of its affiliated clubs throughout the country.

Philippine Airlines provided reduced air fares so that hundreds of volunteers could converge on Apo for the replanting. This national conservation action was the first of its kind, and illustrates the sympathy and awareness that are now developing in the country. The project was an initial success, but it is still too early to know how well the indigenous trees will recolonize. The BFD and MACADAC are still planting seedlings and clearing fire-breaks.

In 1984 'Friends of Mt Apo National Park' was set up by the BFD in Davao City. It includes members of the general public, interested local groups, regional government officials and members of the BFD. The aim is to develop public participation in the running of the park, providing a direct input to the Parks and Wildlife Division and co-ordinating the efforts of the various groups.

Although most Filipinos know the park, too few understand its significance. A conservation education programme is needed not just in Davao, but throughout the country. Little rain forest ecology and conservation is taught in schools, and at graduate level the courses are primarily concerned with forestry. A conservation campaign using newspapers, radio and television could reach even those living in the mountains. From discussions I had in Davao, the media are quite willing to undertake this, but lack the necessary information. At present, the only book on Mt Apo is the guide written by Rey Soroñgon (1982), a member of MACADAC. More literature is needed, as are information boards at all the park entrances. The Haribon Foundation, a national conservation group, is preparing education materials concerned with rain-forest conservation, and has also proposed a study of the national park system in the Philippines.

In the past, management of native peoples has tended to take control from them in the belief that this would minimize environmental damage. However, on the island of Luzon, Rice (1984), working with the native Ikalahans, found that their approach to the forest changed Oryx Vol 22 No 2, April 1988 


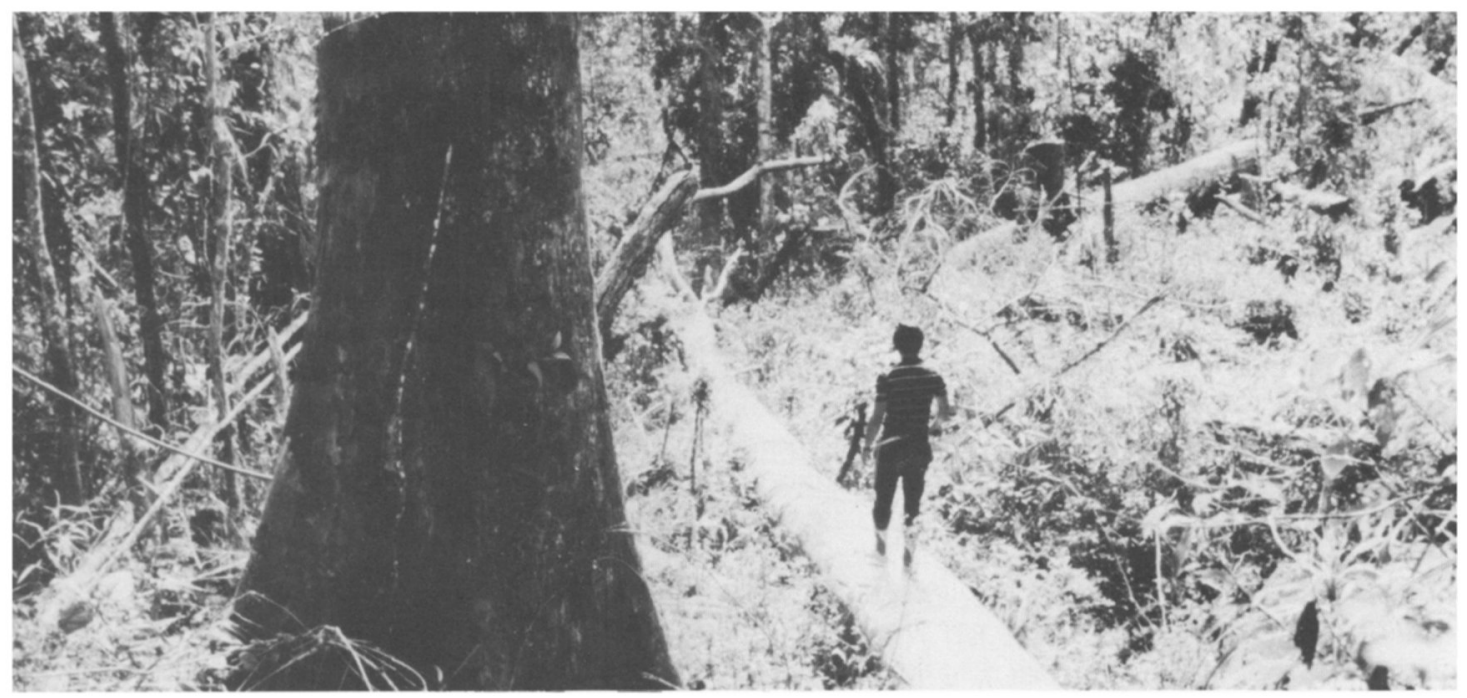

New kaingin being cleared at approximately $1000 \mathrm{~m}$ altitude (R. E. Lewis).

when given more control over their own activities. A formal agreement between the tribe and the BFD stated what the BFD required of the area (which is a valuable watershed) and left it to the tribe to organize itself. Previous to the agreement upwards of 400 ha of grassland were burnt each year. In 1984 this was down to 40 ha a year, but the Ikalahans were trying to reduce it further. The tribe fined individuals for irresponsible burnings. Certainly a scheme like this is required around $\mathrm{Mt}$ Apo. With good dialogue and some form of security of tenure, progress can be achieved that is both beneficial for the forest and the people. Similarly, it has been suggested (Siebert, 1984) that illegal settlers should be offered land stewardship titles in return for legal agreement that they do not move from the land they occupy. In conjunction, agro-forestry assistance would be offered to enable the farmer to utilize the land year after year. This could work only if new immigration is controlled and proper forest protection is enforced.

To the south of Mt Apo, in Alah valley, a craft industry has been established for the products of the T'boli people. Native crafts offer great potential in creating revenue for the local people of $\mathrm{Mt} \mathrm{Apo,} \mathrm{especially} \mathrm{if} \mathrm{tourism} \mathrm{is}$ involved in the park. The farming of rattans and other minor forest products (such as orchids, National parks in the Philippines butterflies, medicinals and spices) could also generate a substantial income for the community.

\section{Tourism}

It is not known how many people visit the park each year, but it is certainly in the thousands. In 1985 over 1000 people visited the Philippine Eagle Centre alone, and during Easter week hundreds of Filipinos trek to the peak for enjoyment and pilgrimage. Sights on the Davao side include the magnificent Tudaya Falls on the Sibulan river. Hot springs are found in the park, and Lake Agco is near boiling point. Water is tapped from the lake into a 5-m diameter tub, where it is mixed with cold water piped from a nearby stream. After a day's hiking the effect has to be felt to be believed. At Mitondo, Philippine eagles can regularly be seen. For four months in 1983 we had a hide near an eagle nest so that people could view the birds without disturbing them. As an education tool and a park attraction, a hike through the rain forest then a sight of the Philippine eagle is unsurpassed. A wilderness trekking programme in Khao Yai National Park in Thailand has increased revenue for the local villagers and created new attitudes to the forest, resulting in less tree cutting and poaching (Suvanakorn and Dobias, 1986). 
Visitors to the park should give themselves three to five days to enjoy the hike. It is not an easy hike to the peak; steep terrain and possible inclement weather face the hiker. Frosts are occasionally recorded at the peak, and difficult conditions are normal between November and December. As yet there is no system of official guides and porters for the park, but MACADAC is training people from the local community of New Israel. Organized hiking is needed to minimize the hikers' impact and create revenue for the park. As more and more people use the park, unintentional damage is increasing. Lake Venado is threatened by too many campers spreading around the lake. Most hikers still use firewood for cooking, and the turf around the lake is damaged by fires and compaction. Control is needed to prevent pollution of the lake, which is an important source of drinking water for hikers. Rangers are needed at Lake Agco, Lake Venado and the forest above Tudaya, the three areas commonly used for camping. Monitoring is necessary to prevent the collection of epiphytes or else the well-known trails will soon be devoid of beauty. Litter is common on the trails, but this could be lessened through informing hikers of the problem. There should be a charge for people wishing to stay in the park, with a reduced rate for local people. Money could also be generated by rental of huts (presently at New Israel, Lake Agco and the Philippine Eagle Centre) and supplying foodstuffs. Brad Warren of AREA believes that adventure tourism is ideal for Philippine conservation (Warren, 1982). With a $\$ 10$ million investment he estimates an additional $\$ 200$ million would be created annually, and imposing a $15^{1 / 4}$ per cent tax on this would generate enough funds for park management throughout the country.

\section{Other forest parks in the Philippines}

The only other large park on Mindanao is $\mathrm{Mt}$ Malindang National Park $(50,000$ ha). It has similar problems to Apo. A new national park, Mt Katanglad, has recently been proposed. Both Mt Malindang and Mt Katanglad hold Philippine eagles. Some areas of lowland forest can still be found on the western peninsula, and 108 even if these have already been selectively logged, efforts should be made to create some form of reserve to allow the regeneration of the rain forest. It is unrealistic at present to try to preserve virgin lowland forest; economic pressures are too great.

On Luzon there are four parks that contain rain forest, but unfortunately these are small (the largest is $5000 \mathrm{ha}$ ) and/or isolated from other forests. None holds Philippine eagles, which do occur on Luzon. The largest tracts of forest are in the Sierra Madre mountains along the east coast. A large park of at least 50,000 ha should be established there for the Philippine eagle, before the lowland forest is lost.

Palawan is still relatively undeveloped and offers the greatest chance of immediate success with forest conservation. It presently has one forest park of approximately 5000 ha surrounding St Paul's subterranean river. More are needed. A summary of the situation is described by Balmford and Quinnell (1988).

The two notable rain-forest parks outside these three islands are $\mathrm{Mt}$ Canlaon (approximately $25,000 \mathrm{ha}$ ) on Negros and, the largest park in the country, Mt Iglit (75,000 ha) on Mindoro. Mt Canlaon contains the endangered Visayan warty pig Sus barbatus cebifrons (Cox, 1987), and Mt Iglit is home to the endemic buffalo, the tamaraw Bubalus mindorensis and the indigenous Mangyan peoples. Both parks are being cleared on the borders and suffer from poaching. There are also plans for geothermal energy development around Mt Canlaon, an active volcano.

On Leyte, a new national park has been proposed (1982), Leyte Mountains National Park (approximately $40,000 \mathrm{ha}$ ). Although not yet fully surveyed it probably contains the endangered Cervus alfredi, the endemic deer of the central Philippines. Establishment of the park will probably be hampered by proposed plans for extensive geothermal-industrial projects, road construction through the middle of the park, and human resettlement programmes (Siebert, 1984). If this new park could be maintained it will form a vital link, with Mt Canlaon, in the preservation of the central Philippines' wildlife.

Oryx Vol 22 No 2, April 1988 
Logging concessions around the national parks need to be managed on a sustainable yield system, and human immigration prevented. This will provide a buffer zone between the fully protected forests of the parks and agricultural development. Normally the mossy forest areas in concessions are not logged, as the small trees and steep terrain make it uneconomical. I saw an exception to this where a plateau in the Katanglad range, $1700 \mathrm{~m}$, was being logged. The area was already being settled and hundreds of hectares of intact forest had been burnt during the 1982/83 drought. Parks, watershed areas and logging concessions will all have a role to play in rain forest conservation.

\section{Conclusions}

Mt Apo National Park, along with most Philippine parks, needs administrative reorganization, new evaluation and protection. These can only come about through committed finance. The BFD proposed a 4-year development scheme for Apo (1984-1988), which has been shelved due to the lack of the necessary $6,948,581$ pesos $(\$ 347,429$ at the 1984 exchange rate). Unfortunately, the new government is virtually bankrupt with foreign debts over $\$ 25$ billion. Presently none of the parks come up to the international standards defined by the IUCN (Roque, 1985), and although the BFD has stated that the facilities of two parks are to be improved (Agaloos, 1984), this is unlikely in the present financial climate. The biggest problem now is time. Forest clearance is still continuing, uncontrolled, within the parks. Immediate short-term measures are needed to provide a 'stop-gap', while long-term plans are implemented. Five to ten years away may be too late. No matter how little, work has to begin now.

\section{Acknowledgments}

I would like to thank my colleagues in the PECP, BFD, Haribon and MACADAC, especially Florie Andrion, Cora Baylon, Boy Peña, Rey Sorongon, Tony Uy and Ed Viacrucis. Jean Arguillas, Dr Michael Green, Carl Jones, David Todd and Mark Witmer kindly commented on the manuscript.

\section{References}

Agaloos, L.C. 1984. Management of national parks and other protected areas in the Philippines. Proceedings 1st ASEAN Forestry Congress, 6, 787-791.

Anderson, M.B., Ang, L.R. and Taningco, E.M. 1983. An Analysis of Laws and Enactments Pertaining to National Parks. Natural Resources Management Center, Quezon City.

Anon. 1983. Philippine National Conservation Strategy. The Haribon Foundation, Manila.

ASEAN Experts Group on the Environment. 1983. Mt Apo National Park. In ASEAN Heritage Parks and Reserves, pp. 68-73. ROAP/ASEAN/83/3, Bangkok.

Balmford, A. and Quinnell, R. 1988. A future for Palawan's forests? Oryx, 22, 30-35.

Bruce, M.D. 1980. A Field List of the birds of the Philippines. Traditional Explorations, Sydney.

Collins, N.M. and Morris, M.G. 1985. Threatened Swallowtail Butterflies of the World. The IUCN Red Data Book. IUCN Gland.

Cox, R. 1987. The Philippines spotted deer and the Visayan warty pig. Oryx, 21, 37-42.

FAO. 1981. Forest Resources of Tropical Asia. Food and Agricultural Organization of the United Nations, Rome.

Gaon, B.V. 1984. Integrated Environmental Plan for Palawan. Likas-Yaman, 4 (5), 1-52.

Hauge, P., Terborgh, J., Winter, B. and Parkinson, J. 1986. Conservation priorities in the Philippine Archipelago. Forktail, 2, 83-91.

Kellmann, M.C. 1970. Secondary Plant Succession in Tropical Montane Mindanao. Research School of Pacific Studies, Australian National University, Canberra.

Kennedy, R.S. and Catibog-Sinha, C. (eds) The biology and management of the Philippine Eagle Pithecophaga jefferyi. (in prep).

Lewis, R.E. 1986. A rain-forest raptor in danger. Oryx, 20, 170-175.

Pollisco, F.S. 1982. An Analysis of the National Park System in the Philippines. Likas-Yaman, 3 (12), 1-56.

Rice, D. 1984. Indigenous Forest dwellers in Forest Development Planning. Proceedings 1st ASEAN Forestry Congress, 5, 756-769.

Roque, C. 1985 . The state of our national parks and how to save them. Enviroscope, 5 (1), 1-2.

Siebert, S.F. 1984. Conserving tropical rainforest: the case of Leyte Mountains National Park, Philippines. In Mountain Research and Development (eds B. Messerli and J.D. Ives), 272-276

Sorongon Jr, R.G. 1982. The First Guide to climbing Mt Apo. Private publication, Davao City.

Suvanakorn, P. and Dobias, R.J. 1986. Cash Incentives for Protection. IUCN Bulletin, 17 (1-3), 33.

Warren, B. 1982. Comments during the discussion period. 1st National Conservation Conference on Natural Resources. NRMC, Quezon City.

Richard E. Lewis, Hollinsclough, Forest Road, Oakmere, Nr Northwich, Cheshire CW8 2DY, UK 